\title{
Reduction of Uterine Perfusion Pressure Induced Redistribution of Endothelin Receptor Type-B Between the Intima a. Media Contributes to the Pathogen Pregnancy-Induced Hypertensio
}

\author{
Yuan Sun ${ }^{\mathrm{a}}$ Xicheng Zhang ${ }^{\mathrm{a}}$ Zhaolei Chen ${ }^{\mathrm{a}}$ Miao \\ aDepartment of Vascular Surgery, Subei People's Hospital of Jiangsu \\ College of Yangzhou University, Yangzhou; bDepartm of Vascular S \\ Ningxia Hui Autonomous Region, Yinchuan, China \\ e, ti.uc Clinical Medical \\ ry, People's Hospital of
}

Key Words

Pregnancy-induced hypertension pressure $\cdot N F-k B$

Abstract

Background/Aims: Stur in the artery is related underlying this change endothelin rece of uterine per 18 $\mathrm{PIH}$; the re 'ting intima aor r. re (RUPP) rat model was used to mimic some of the features of have s. in that a change in endothelin receptor expression regn ${ }^{\wedge}$ cy-induced hypertension (PIH). However, the mechanism unclear. Methods: To test whether the distribution of and non s: Co ed with NP rats, RUPP rats had a significant redistribution of $E T_{B} R$ expression tima and media, while there was no significant difference in $E T_{A} R$ expression between ps. $\mathrm{ET}_{\mathrm{B}} \mathrm{R}$ upregulation in VSMCs enhanced cellular contraction and contributed to The TNF- $\alpha$ plasma levels in RUPP rats were two-fold higher than those of NP rats, which clusion: Redistribution of $\mathrm{ET}_{\mathrm{B}} \mathrm{R}$ between the media and intima played an important role in pathogenesis of PIH.

Y. Sun and X. Zhang contributed equally to this manuscript. 


\section{Cellular Physiology Cell Physiol Biochem 2017;44:1715-1725

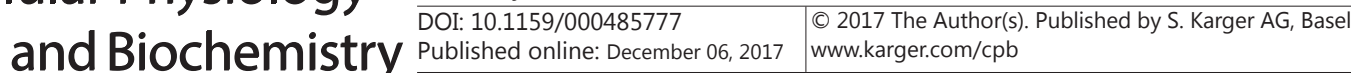 \\ Sun et al.: ETBR Redistribution Contributes to Pregnancy-Induced Hypertension}

\section{Introduction}

Preeclampsia is a pregnancy-induced hypertensive disorder that is characterized by severe hypertension, proteinuria, eclampsia and seizures [1]. It is one of the leading causes of maternal and perinatal morbidity; however, the underlying mechanisms are not clear. normal pregnancy (NP) is associated with decreased vascular resistance, increased cardi. output, and a slight reduction or no change in blood pressure [2,3]. Instead of these beneficial changes, vascular resistance and arterial pressure are greatly increased in women sufferi from preeclampsia.

Placental ischemia induced inflammatory cytokine production during gnan an important initiating event in preeclampsia, because it induces structural and ctic alterations in endothelial cells that results in the release of oxidizing free'radica. formation of lipid peroxides. The lipid peroxides and oxygen radical comp damage endothelial cells. Moreover, the inflammatory cytokines also pror of a number of endothelial cell substances, which enhance vasoconstric

Endothelin-1 (ET-1) is a major endothelium-derived factor th of the most potent vasoconstrictors; ET-1plays an import int role it of the most potent vasoconstrictors, ET-1plays an impor role in pathogenesis of preeclampsia $[1,4,7]$. Plasma ET-1 concentrations durin mpsia pproximately two- to three-times higher than normal levels, and ET-1 h igh long-term effects on arterial pressure regulation [8-10]. However, some studies elevation in plasma endothelin in preeclampsia atients [11]. ddition, ET-1 is considered to be involved in the progression of preeclam thus, the exact role of endothelin is unknown [7|.

From in-depth research, it was discove receptors type-A $\left(\mathrm{ET}_{\mathrm{A}} \mathrm{R}\right)$ and type- $\mathrm{B}\left(\mathrm{ET}_{\mathrm{B}} \mathrm{R}\right)$ smooth muscle cells (VSMCs) to induce vaso expressed in endothelial cells (ECs) to aiding ET-1 clearance [13]. ET $\mathrm{R}$ was pregnancy-induced hyperten ${ }^{A} \mathrm{R}$ 'PIK PIH $[14,15]$. However, $\mathrm{ET}_{\mathrm{B}} \mathrm{R} \mathrm{u}$ . incs was also found to be associated with many cardiovascular diseases and ribute to vasoconstriction [13, 16-19]. Mazzuca et al. reported that downregul of $\mathrm{E}$ microvascular endothelial cells is a central vascular mechanism of PIH [20]. r preyious results have demonstrated that $\mathrm{ET}_{\mathrm{B}} \mathrm{R}$ upregulation in the intima and downreg the media were associated with adaptive vasodilation in pregnant rats [1 dence has shown that $\mathrm{ET}_{\mathrm{B}} \mathrm{R}$ expression/activity in ECs and VSMCs could $r$ by cytokines such as TNF- $\alpha$ through the protein kinase C (PKC), extracellul-regy ec tein kinase 1 and 2 (ERK1/2) and NF-кB pathways [17, 21-23]. Thus, wey cula placental ischemia induced inflammatory cytokine production may regulat redistrioution of $\mathrm{ET}_{\mathrm{B}} \mathrm{R}$ expression in the intima and media of the artery and but e pathogenesis of preeclampsia.

"ered $\mathrm{s}$ on of uterine perfusion pressure (RUPP) ratmodel mimics some of the features or p. Ssia, including PIH, endothelial dysfunction, and increased vasoconstriction [24].

pistudy aimed to explore the endothelin receptor expression change between the $\checkmark \mathrm{PP}$ and NP rat models, which may provide new insights into the underlying molecular an anisms of PIH.

\section{Materials and Methods}

\section{Animals}

The animal experiments in the present study were approved by the Animal Care and Use Committee of Yangzhou University. Sprague-Dawley rats (12 weeks of age) were purchased from HFK Bioscience (Beijing, China). Rats were maintained in a pathogen-free barrier facility at Yangzhou University.

On day 14 of pregnancy, rats underwent either sham-operations or surgical procedures to reduce the uteroplacental perfusion pressure. On day 18 of pregnancy, the mean arterial pressure (MAP) was recorded. The RUPP procedure and measurement of the MAP were performed as described previously [20].

\section{KARGER}




\section{Cellular Physiology Cell Physiol Biochem 2017;44:1715-1725

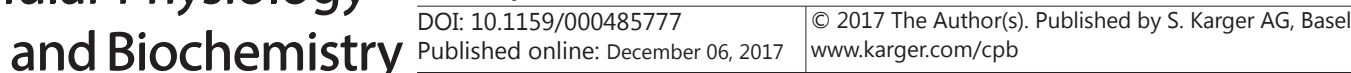 \\ Sun et al.: ETBR Redistribution Contributes to Pregnancy-Induced Hypertension}

Isolation of single vascular smooth muscle cells and measurement of cellular contraction

Single aortic VSMCs were freshly isolated, and cellular contraction was measured as previously described [16]. Freshly isolated aortic VSMCs were placed on a slide and the cell images were acquired by a Nikon digital camera and image acquisition software. After measuring the length of resting cells, the cells were stimulated with ET-1 $\left(10^{-6} \mathrm{M}\right)$ for $10 \mathrm{~min}$, and the changes in cell length were measured. Then selecti$\mathrm{ET}_{\mathrm{A}} \mathrm{R}$ antagonist $\mathrm{BQ123}\left(10^{-6} \mathrm{M}\right), \mathrm{ET}_{\mathrm{B}} \mathrm{R}$ antagonist $\mathrm{BQ788}\left(10^{-6} \mathrm{M}\right)$ and the $\mathrm{ET}_{\mathrm{B}} \mathrm{R}$ agonists IRL-1620 $\left(10^{-6} \mathrm{~N}\right.$ were added together with ET-1separately, and the cell lengths were recorded. The magnitude of cellular contraction was expressed as $\left(\mathrm{L}_{\mathrm{i}}-\mathrm{L}_{\mathrm{f}}\right) / \mathrm{L}_{\mathrm{i}} \times 100 \%$, where $\mathrm{L}_{\mathrm{i}}$ represents the initial cell length and $\mathrm{L}_{\mathrm{f}}$ repres the final cell length.

\section{ELISA}

The plasma concentration of ET-1and the related inflammatory factors were determined Kit following the manufacturer's protocols: Rat Endothelin 1 ELISA Kit (Abcam, at ELISA kit (Abcam, ab46070), Rat IL-1 ELISA Kit (Abcam, ab100768), Rat IL-2 ELISA Kit Rat IL-6 ELISA Kit (Abcam, ab100772), Rat IL-6 ELISA Kit (Elabscience, E-EL-R0560 Kit (Abcam, ab113349), and Rat MCP1 ELISA Kit (Abcam, ab219045). Absorb microplate reader (Thermo Scientific).

\section{Immunohistochemistry and immunofluorescence staining}

Three sections from each graft were stained with HE Immunohistochemistry and immunofluorescence was performed sections were incubated overnight with anti-ET $\mathrm{A}_{\mathrm{A}}\left(\mathrm{A}^{\prime} \quad \mathrm{n}\right.$, ab85163)
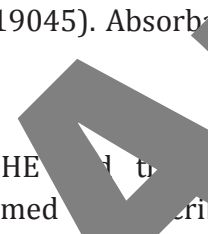

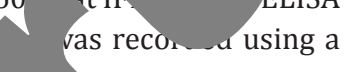
sections were double stained by anti-CD 31(Abcam, ab and anti- $\alpha$-SMA (Abcam, ab28052) with anti-ET $\mathrm{R}_{\mathrm{B}} \mathrm{R}$ (Abcam, ab117529) by immunofluoresce $\mathrm{Ne}_{\mathrm{S}}$ controls were included using isotypematched control antibodies (Abcam). In the control e men ner the primary antibody or secondary antibody was omitted. The stained arterial se ved under a confocal microscope (Nikon, C1plus, Nikon Instruments, Inc, NY, USA) a (1ta $d$ by IviAGE-PRO PLUS. For quantification, the mean optical densities of the $\mathrm{ET}_{\mathrm{A}} \mathrm{R}$ and $\mathrm{ET}_{\mathrm{B}} \mathrm{R}$ st:
using IMAGE-PRO PLUS. In each optical density was obtained from

Western blot

The aortas were froze liquid nitrogen and homogenized in a cell extract denaturing buffer that contained a phosphatase in $\quad \mathrm{il}$ and protease inhibitor cocktail. The cultured cells were resolved using RIPA Lysis Buf for $\mathrm{ET}_{\mathrm{A}} \mathrm{R}$ (Abcam, ab85163), $\mathrm{ET}_{\mathrm{B}} \mathrm{R}$ (Abcam, ab117529), phospho-NF-

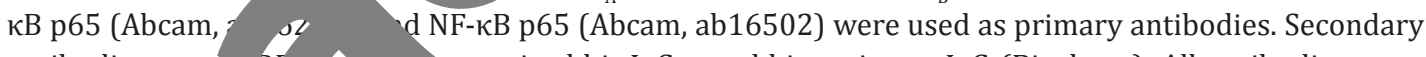
antibodies ware $R$ be sat anti-rabbit IgG or rabbit anti-goat IgG (Biosharp). All antibodies were used at a dil $\quad \mathrm{A}$ of the experiments were repeated 3 times. An anti-GAPDH antibody (Bioworld, AP0063, ised for... imalization. The western blot band intensity was determined using IMAGE-PRO

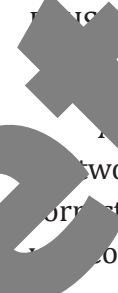
a analy,

are expressed as the mean \pm SEM. Unpaired and paired Student's $t$ tests were performed wo-group comparisons and one-way ANOVA was used for multi-group comparisons. The Bonferroni tion was used to identify the difference between each two groups after one-way ANOVA test. P $<0.05$ onsidered significant. All experiments were repeated 3-5 times.

\section{Results}

The mean arterial pressure was higher in RUPP rats than NP rats without significant vascular remodeling

On gestation day 18, RUPP in pregnant rats resulted in significant increases in MAP, which was approximately $20 \mathrm{mmHg}$ higher than in NP rats (Fig. 1A). The thoracic aortas of RUPP rats and NP rats were harvested for pathological examination. HE staining revealed no significant difference in the thicknesses of the intima and media between the RUPP and 


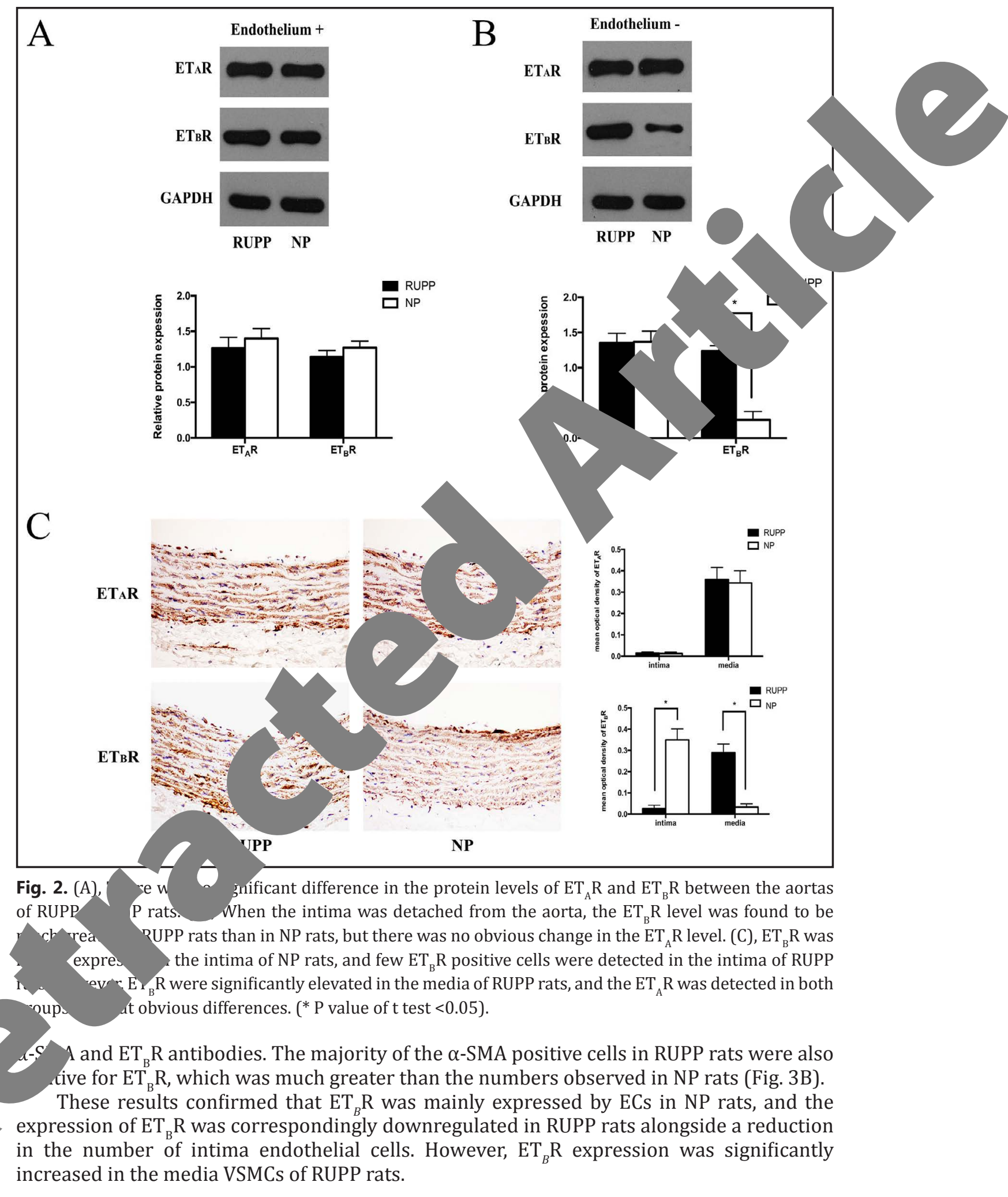

The increased $E T_{B} R$ in VSMCs contributed to cellular contraction and enhanced the function of $E T_{A} R$

To test the function of $\mathrm{ET}_{\mathrm{A}} \mathrm{R}$ and $\mathrm{ET}_{\mathrm{B}} \mathrm{R}$ in VSMCs, single aortic VSMCs were freshly isolated from the aortas of NP and RUPP rats. Spindle-shaped cells $\geq 50 \mu \mathrm{m}$ in length were selected KARGER 


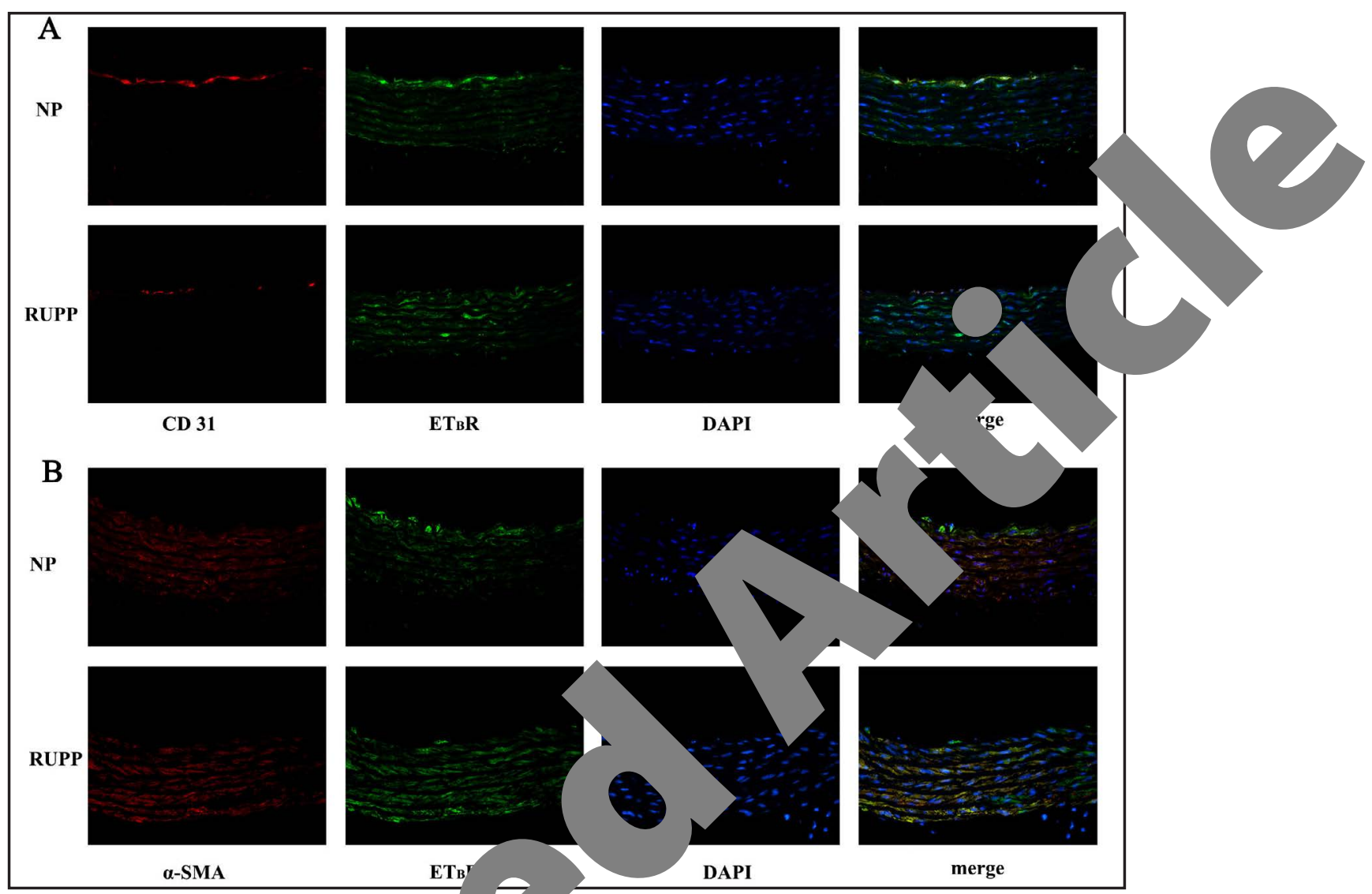

Fig. 3. (A), Most of the CD 31-positive cel la were positive for $\mathrm{ET}_{\mathrm{B}} \mathrm{R}$, but the number of CD 31-positive cells was significantly cells in RUPP rats were also positi Ru an in NP rats. (B), The majority of the $\alpha$-SMA positive $\mathrm{T}_{\mathrm{B}} \mathrm{R}$, wrincn was much greater than in NP rats.

for study. There was no lificant ànerence between the two groups. ET-1 $\left(10^{-6} \mathrm{M}\right)$ caused greater contraction in $V$ for RUPP rats than those from NP rats (Fig. 4A). When the VSMCs of RUPP ar $\mathrm{ra}$ pretreated with the ETAR antagonist BQ123 $\left(10^{-6} \mathrm{M}\right)$ for 10 min, ET-1-indu ction was inhibited in both groups. However, the ET-1induced contraction in VS When VSN we reated with both BQ123 $\left(10^{-6} \mathrm{M}\right)$ and the $\mathrm{ET}_{\mathrm{B}} \mathrm{R}$ antagonist BQ788 $\left(10^{-6} \mathrm{M}\right.$-indu contraction was almost negligible in both groups (Fig. $\left.4 \mathrm{C}\right)$.

Co to the previous results, we deduced that the upregulated $\mathrm{ET}_{\mathrm{B}} \mathrm{R}$ in smooth e cells anced the ET-1-induced contraction in RUPP rats. To test our hypothesis, t. "oup chas much more significant in the VSMCs of RUPP rats than in those of NP rats g. 4D).

TNF- $\alpha$ induced upregulation of $E T_{B} R$ in cultured VSMCs through NF- $\kappa B$ related pathways

The NF- $\kappa B$ signaling pathway has been reported to mediate $\mathrm{ET}_{\mathrm{B}} \mathrm{R}$ expression in VSMCs of resistance arteries [25]. Thus, we attempted to elucidate whether NF- $\kappa B$ is involved in the upregulation of $\mathrm{ET}_{\mathrm{B}} \mathrm{R}$ in the aorta VSMCs of RUPP rats. First, the NF- $\kappa \mathrm{B}$ and p-NF- $\mathrm{BB}$ p65 levels of aortas from RUPP and NP rats without intima were determined by western blotting. The p-NF-кB p65 level was significantly higher in media VSMCs from RUPP rats than those from NP rats (Fig. 5A).

Then, the concentrations of several proinflammatory cytokines related to PIH were measured by ELISA [6]. Similar to previous reports, several cytokines were increased more

\section{KARGER}


Fig. 4. (A), ET1 caused greater contraction in the VSMCs from RUPP rats than from NP rats. (B), ETAR antagonist BQ123 alleviatedET-1 induced contraction in both groups. However, ET1-induced contraction was still greater in VSMCs from RUPP rats than from NP rats. (C), BQ123 and the ETBR antagonist BQ788 completely abolished the ET1induced contraction in both groups. (D), The ETBR agonist IRL-1620 caused a persistent contraction in both groups, which was much more significant in VSMCs from RUPP rats than from NP rats. (* $\mathrm{P}$ value of $t$ test $<0.05$ ).
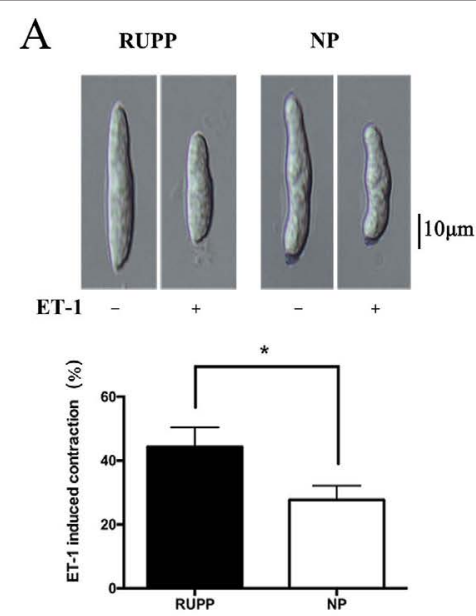

$\mathrm{C}$
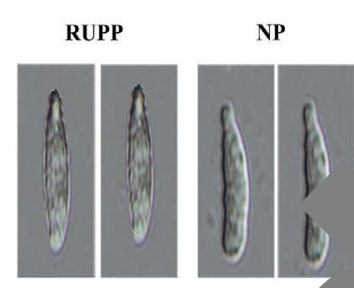

ET-1

BQ-123 + BQ-123
BQ-788

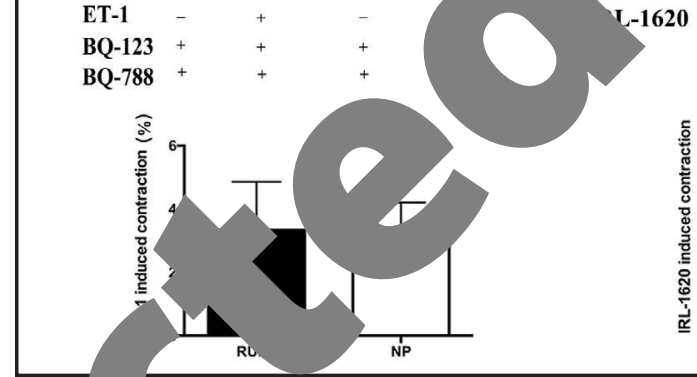

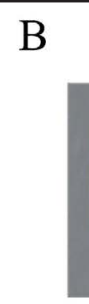

ET-1
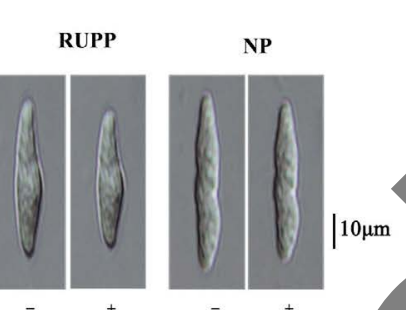

$\mathrm{BQ}-123+$
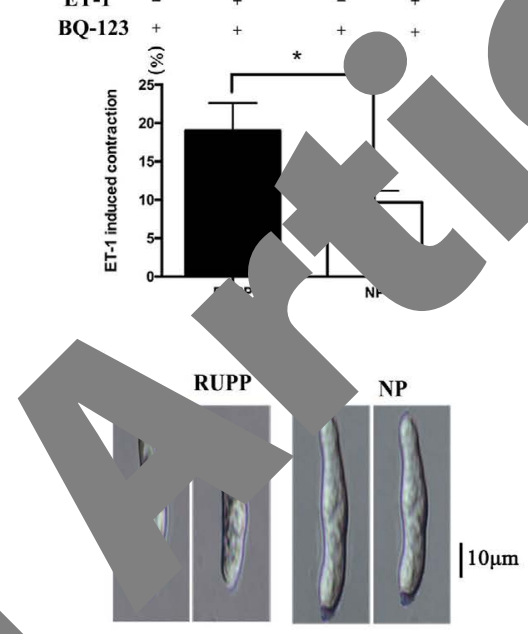

$10 \mu \mathrm{m}$

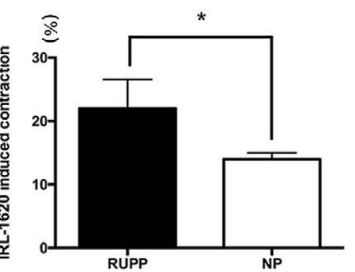

than 1.5-fold in RUDP ra

been reported

activation of $\mathrm{k}$

such as $\mathrm{T}-\alpha$, id pathwar ing t

d) $r$ ng TNF- $\alpha$ and IL-6, IL-8, and MCP-1(Fig. 5B). TNF- $\alpha$ has
Therefore, we postulated that some of the elevated cytokines process.

To ur speculation, VSMCs from the aortas of NP rats were cultured in vitro. The ed V. from NP rats were co-incubated with TNF- $\alpha$ for 24 hours, and then p-NFand $\mathrm{E}_{\mathrm{B}} \mathrm{R}$ protein levels were measured. Both p-NF- $\mathrm{KB}$ p65 and $\mathrm{ET}_{\mathrm{B}} \mathrm{R}$ expression incre th an increased concentration of TNF- $\alpha$. When NF- $\kappa B$ activation was blocked an Nr-KB inhibitor (BAY11-7082), TNF- $\alpha$ induced $\mathrm{ET}_{\mathrm{B}} \mathrm{R}$ upregulation was abolished (Fig. C) Thus, we determined that TNF- $\alpha$ upregulated the expression of $\mathrm{ET}_{\mathrm{B}} \mathrm{R}$ in VSMCs through

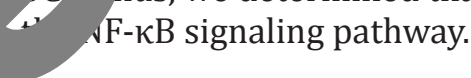

\section{Discussion}

Our results proved that: (1) the increased plasma TNF- $\alpha$ expression in RUPP rats could induce upregulation of $\mathrm{ET}_{\mathrm{B}} \mathrm{R}$ in VSMCs through the NF- $\kappa \mathrm{B}$ signaling pathway; (2) redistribution of $\mathrm{ET}_{\mathrm{B}} \mathrm{R}$ but not $\mathrm{ET}_{\mathrm{A}} \mathrm{R}$ was associated with the pathogenesis of PIH; and (3) the expression of $\mathrm{ET}_{\mathrm{B}} \mathrm{R}$ in media VSMCs enhances vasoconstriction in RUPP rats. 


\section{Cellular Physiology Cell Physiol Biochem 2017;44:1715-1725

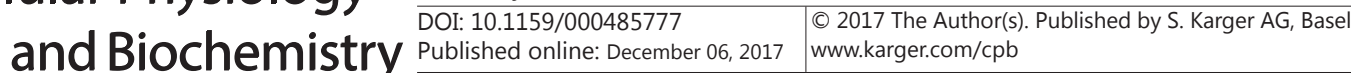

\section{References}

1 George EM, Granger JP: Endothelin: Key mediator of hypertension in preeclampsia. Am J Hypertens 2011;24:964-969.

2 Gillis EE, Sasser JM, Sullivan JC: Endothelin, sex, and pregnancy: Unique considerations for blood pressur control in females. Am J Physiol Regul Integr Comp Physiol 2016;310:R691-696.

- 3 Granger JP, Alexander BT, Bennett WA, Khalil RA: Pathophysiology of pregnancy-induced hypertension. Am J Hypertens 2001;14:178S-185S.

4 Granger JP, Alexander BT, Llinas MT, Bennett WA, Khalil RA: Pathophysiology of hypertension-during preeclampsia linking placental ischemia with endothelial dysfunction. Hypertension 2001,

5 Hariharan N, Shoemaker A, Wagner S: Pathophysiology of hypertension in preeclampsia. Micr 2016;109:34-37.

6 Raghupathy R: Cytokines as key players in the pathophysiology of preeclampsia. Med 2013;22:8-19.

7 LaMarca BD, Alexander BT, Gilbert JS, Ryan MJ, Sedeek M, Murphy SR, Granger JP-F hypertension in response to placental ischemia during pregnancy: A central ro 2008;5:S133-138.

8 Roberts JM, Taylor RN, Musci TJ, Rodgers GM, Hubel CA, McLaugi disorder. A J Obstet Gynecol 1989;161:1200-1204.

-9 Clark BA, Halvorson L, Sachs B, Epstein FH: Plasma endothelin levels correlation with uric acid levels and renal impairme J Obstet Gyn

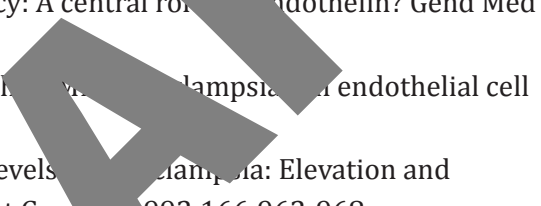

$\checkmark 10$ Wilkins FC, Alberola A, Mizelle HL, Opgenorth TJ, Gra $\quad$ : Systemic h dynamics and renal function during long-term pathophysiological increases in circh dothelin. A J Physiol 1995;268:R375-R381.

-11 Gilbert JS, Gillham HE, Regal JF: Down but not out: ner le for the b-type endothelin receptor in placental ischemia-induced hypertension. Hyperte

12 Shihoya W, Nishizawa T, Okuta A, Tani K, Do endothelin etb receptor by endothelin-1.

13 Mazzuca MQ Khalil RA: Vascular endoth vascular disease. Biochem $\mathrm{Ph}$

14 Tam Tam KB, George E, Cockre nyy M, Spuc J, Martin JN, Jr., Lamarca B, Granger JP: Endothelin type a receptor antagonist atter tes $\mathrm{p}_{2} \quad$ hemia-induced hypertension and uterine vascular resistance. Am J Obstet Gynecol $201 \quad$ 4:330 es, 4.

-15 Alexander BT, Rinewalt Cockre" 'KL, Massey MB, Bennett WA, Granger JP: Endothelin type a receptor blockade attenuatoc the
Hypertension in response to chronic reductions in uterine perfusion pressure. muscle cells during pregnancy in rats. J Cell Physiol 2014;229:489-501.

17 Beg iz JA, Vikman PJ, Xu CB, Edvinsson LI: Protein kinase c inhibition prevents

upre. n of vascular et(b) and 5-ht(1b) receptors and reverses cerebral blood flow reduction after barac. haemorrhage in rats. J Cereb Blood Flow Metab 2007;27:21-32.

- son D, 、rckenfors A, Gustafsson L, Edvinsson L, Paulsson P, Ingemansson R, Malmsjo M: Increased et(a) receptor contraction in the left internal mammary artery from patients with hypertension. J Hum

B y Wackenfors A, Emilson M, Ingemansson R, Hortobagyi T, Szok D, Tajti J, Vecsei L, Edvinsson L, Malmsjo M: ischemic heart disease induces upregulation of endothelin receptor mrna in human coronary arteries. Eur J Pharmacol 2004;484:103-109.

20 Mazzuca MQ Li W, Reslan OM, Yu P, Mata KM, Khalil RA: Downregulation of microvascular endothelial type $\mathrm{b}$ endothelin receptor is a central vascular mechanism in hypertensive pregnancy. Hypertension 2014;64:632-643.

21 Chen Y, Liu H, Zhang H, Liu E, Xu CB, Su X: The sirt1/nf-kb signaling pathway is involved in regulation of endothelin type $\mathrm{b}$ receptors mediated by homocysteine in vascular smooth muscle cells. Biomed Pharmacother 2016;84:1979-1984. 


\section{Cellular Physiology Cell Physiol Biochem 2017;44:1715-1725

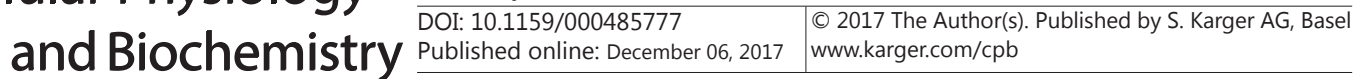 \\ Sun et al.: ETBR Redistribution Contributes to Pregnancy-Induced Hypertension}

-22 Zheng JP, Zhang Y, Edvinsson L, Hjalt T, Xu CB: Nf-kappab signaling mediates vascular smooth muscle endothelin type b receptor expression in resistance arteries. Eur J Pharmacol 2010;637:148-154.

-23 Uddman E, Moller S, Adner M, Edvinsson L: Cytokines induce increased endothelin et(b) receptor-mediated contraction. Eur J Pharmacol 1999;376:223-232.

-24 Thaete LG, Neerhof MG: Endothelin and blood pressure regulation in the female rat: Studies in normal pregnancy and with nitric oxide synthase inhibition-induced hypertension. Hypertens Pregnancy 2000;19:233-247.

25 Ajlan AM, Sayegh K, Powell T, David H, Riha RM, Khan J, Nahal A: Angiomatoid fibrous histiocytoma: Magnetic resonance imaging appearance in 2 cases. J Comput Assist Tomogr 2010;34:791-794.

26 Hopkins PN: Molecular biology of atherosclerosis. Physiol Rev 2013;93:1317-1542.

-27 Kitada K, Yui N, Koyama M, Kimura K, Suzuki R, Tanaka R, Mori T, Ohkita M, Matsumura Y: End receptor is involved in sex differences in the development of balloon injury-induced nf Pharmacol Exp Ther 2011;336:533-539.

28 Kitada K, Yui N, Matsumoto C, Mori T, Ohkita M, Matsumura Y: Inhibition of endothe system aggravates neointimal hyperplasia after balloon injury of rat carotid arterv. 2009;331:998-1004.

29 LaMarca BB, Cockrell K, Sullivan E, Bennett W, Granger JP: Role of $\theta$ helin in m factor-induced hypertension in pregnant rats. Hypertension 200

30 Davis JR, Giardina JB, Green GM, Alexander BT, Granger JP, Khalil R relaxation pathway during tnf-alpha-induced hypertension in pregn Comp Physiol 2002;282:R390-399.

-31 Kim JH, Na HK, Pak YK, Lee YS, Lee SJ, Moon A, Surh kinases in phorbol ester-induced nf-kappab activationcells. Chem Biol Interact 2008;171:133-141.

-32 N'Guessan PD, Temmesfeld-Wollbruck B, Zahlten J, Suttorp N, Slevogt H: Moraxella catarrhalis e2 in lung epithelium. Eur Respir J 2007;

33 Chen Y, Zhang H, Liu E, Xu C-b, Zhang Y: smooth muscle cells. Vascular
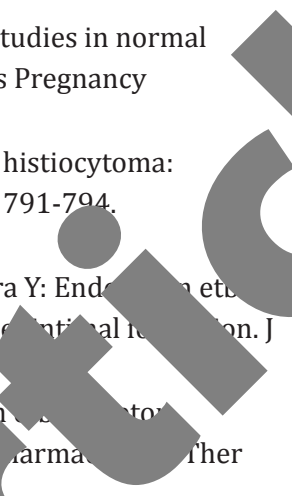
$0-109$. 